\title{
LITTERFALL PRODUCTION IN MANGROVE FORESTS OF THE SÃO FRANCISCO RIVER ESTUARY, SERGIPE STATE, BRAZIL
}

\author{
Tiago de Oliveira Santos ${ }^{1 *}$, Francisco Sandro Rodrigues Holanda ${ }^{2}$, Luciano Carlos Sobral de \\ Menezes $^{2}$, Karen Viviane Santana de Andrade ${ }^{2}$, Renisson Neponuceno de Araújo Filho ${ }^{3}$ \\ 1*Universidade Federal Rural de Pernambuco, Programa de Pós Graduação em Ciência do Solo, Recife, Pernambuco, \\ Brasil - e-mail (*tiagoosantos@yahoo.com.br) \\ ${ }^{2}$ Universidade Federal de Sergipe, Departamento de Engenharia Agronômica, São Cristovão, Sergipe, Brasil - e-mail \\ (fholanda@infonet.com.br; luciano_punka@hotmail.com; karenvivia@hotmail.com) \\ ${ }^{3}$ Universidade Federal do Tocantins, Curso de Engenharia Florestal, Gurupi, Tocantins, Brasil - e-mail \\ (renisson@uft.edu.br) \\ Recebido para publicação: 16/05/2018 - Aceito para publicação: 31/05/2019
}

\begin{abstract}
Resumo
Produção de serapilheira em floresta de mangue do estuário do Rio São Francisco, estado de Sergipe, Brasil. A produção de serapilheira contribui para os modelos de fluxo e conteúdo de carbono essencial para a dinâmica ecossistêmica. O presente estudo tem como objetivo comparar as taxas de produção de serapilheira em bosques de mangue da Costinha, estuário do rio São Francisco, Sergipe para compreensão das variações interanuais da produção total e de seus componentes. Para o monitoramento da produção de serapilheira, o manguezal da Costinha foi estratificado em estações denominadas A, B, C, D e E, utilizando os canais como divisores das mesmas. Em cada estação foram delimitados bosques representativos da estação, e para cada bosque foram alocadas 10 (dez) coletores, com área de $0,25 \mathrm{~m}^{2}$ cada, totalizando 120 cestas para o monitoramento mensal, com duração de dois anos. O material coletado foi separado em frações: folha, flor, fruto, galho, estípula e miscelânea, sendo folhas e frutos separados por espécie. A produção média de serapilheira foi de $13,53 \mathrm{tha}^{-1}$ $\mathrm{ano}^{-1}$ no primeiro ano e $13,21 \mathrm{t} \mathrm{ha}^{-1}$ ano $^{-1}$ no segundo ano, não apresentando diferenças estatísticas $(\mathrm{p}>0,05)$ interanuais, no período avaliado. De modo geral, a produção de serapilheira, nas frações apresentaram ordem decrescente: Folhas > Galhos e Ramos > Estípulas > Frutos e Propágulos > Miscelânea > Flores, sendo o compartimento Folhas responsável por $71,46 \%$ da produção total. O manguezal apresentou taxa de caducifolia variável durante o período monitorado, porém verificou-se uma tendência de aumento na queda das folhas nas épocas mais quentes.
\end{abstract}

Palavras-chave: estado de Sergipe; Ecossistema costeiro; Produção primária

\begin{abstract}
Litterfall production contributes to the flow models and carbon content essential for ecosystem dynamics. The objective of the present study was to assess litterfall production rates in the Costinha mangrove forests, São Francisco River Estuary, Sergipe state, Brazil. To this end, litterfall production in the study area was monitored in five stratified stations (A, B, C, D and E) using the same channels as dividers. Ten (10) $0.25 \mathrm{~m}^{2}$ litter collectors, totaling 120 litterbags, were allocated to each forest station for monthly monitoring lasting two years. The collected material was separated into fractions: leaf, flower, fruit, branch and twig, stipule and miscellaneous, and leaves and fruits were separated by species. The average litterfall production was 13.53 ton $\mathrm{ha}^{-1}$.year ${ }^{-1}$ in the first year and 13.21 ton $^{-1} \mathrm{hear}^{-1}$ in the second year, with no statistically significant differences $(p>0.05)$ between the years during the evaluation period. Generally, litterfall production in fractions presented the following descending order: leaves > branches and twigs $>$ stipules $>$ fruits and propagules $>$ miscellaneous $>$ flowers, with the leaf fractions accounting for $71.46 \%$ of the production. The Costinha mangrove forest showed variable litterfall production rates throughout the study period, but there was an increasing trend in leaf fall in warmer seasons.
\end{abstract}

Keywords: Sergipe state; Coastal ecosystem; Primary production

\section{INTRODUCTION}

Forests sequester and store more carbon than any other terrestrial ecosystem and they are a major natural "brake" on climate change (GIBBS et al., 2007). Therefore, vegetation is a stabilizing factor in the circulation of matter in the biosphere and can be substantially influenced by global changes. Carbon from burning fossil fuels and destroying forests is being released into the atmosphere at an unprecedented rate in the Earth's geological history (GAO et al., 2018). 
In response to strength functions that vary in quality, time and intensity, mangroves can form complex forest systems with high biomass production and structural complexity, exhibiting a great structural and functional variability (PANITZ; PORTO FILHO, 1995).

The coastal zone accounts for less than $5 \%$ of the Earth's surface and is one of the most active regions in biogeochemical interactions of the biosphere. However, when it comes to the global carbon flux, its importance has not yet been properly recognized. It considers only terrestrial and oceanic environments (TWILLEY et al., 1992).

The dynamics of the coastal region, where mangroves are inserted, makes them young systems subject to constant modifications of the intertidal terrain, such as a sequence of advances (progression) and retreatment (erosion) of the vegetation cover (SCHAEFFER-NOVELLI, 1987). This ecosystem is characterized by typical woody vegetation adapted to extreme conditions, such as salinity, unconsolidated soil, low oxygen content, and submerged by tides (SOARES et al., 2003; NASCIMENTO et al., 2006).

The main source of net primary production of mangroves is the compartments of the plants disposed of throughout their life cycle, called litterfall. This is a continuous trend throughout the year, with peaks evidenced by phenological and climatic variables, being predominant for the formation of organic debris that represent significant sources of energy in the marine trophic chains (ABOHASSAN et al., 2012).

As a way of quantifying the total production, identifying the temporal distribution, climatic seasonality and phenological patterns, several studies addressing litterfall have been carried out (BERNINI; REZENDE, 2010; SOUZA; SAMPAIO, 2011; VENDRAMI et al., 2012) comparing productivity differences observed along latitudinal gradients and between climatic zones.

Litterfall production studies are important, since they contribute to the definition of flow models and carbon content in certain regions, and more consistently show their ecosystem dynamics (SANCHES et al., 2009). However, according to Larcher et al. (2014), most of the studies on litterfall production use short monitoring periods, usually 12 months, which are not sufficiently long to observe the production variation between the different areas studied.

In the literature, no records have been found on litterfall production and the impacts caused to mangroves by the changes that have occurred in the low river course in the past two decades. Therefore, it is important to carry out studies aimed at contributing to knowledge about the vegetative dynamics of mangroves, thus enabling a better understanding on their formation process and conservation status. The objective present study was to quantify litterfall production rates and understand how climatic seasonality influences their patterns in the Costinha mangrove forests, São Francisco River Estuary, Sergipe state, Brazil.

\section{MATERIAL AND METHODS}

\section{Study area}

This study was carried out in the Costinha mangrove, estuarine region of the São Francisco river (10³1'03" S; 36²6'31" W), which comprises an area of 3.2 ha located between the municipalities of Pacatuba and Brejo Grande in Sergipe state, northeastern Brazil. According to Adema (2012), this estuary covers an area of $35.31 \mathrm{~km}^{2}$, of which $20.39 \mathrm{~km}^{2}$ are mangrove forests. The average annual temperature is $25.7^{\circ} \mathrm{C}$ and the average annual rainfall is $1202 \mathrm{~mm}$, with the heavier rainfall commonly recorded between the months of March and August. Climate in the region is Aw, dry megathermal to sub-humid (ADEMA, 2012), according to the Köppen's classification.

\section{Litter production}

For the characterization of the mangrove, a stratification of the area was carried out in plots (A, B, C, D and E) using the same channels as dividers. Within each station, forests with different floristic composition, architecture and structural development were selected. Ten (10) $0.25 \mathrm{~m}^{2}$ litter collectors, totaling 120 litterbags (Figure 1), were installed in each forest station for monthly monitoring. They were made from PVC pipes using knees for connection, nylon mesh $(1 \mathrm{~mm})$, and seals to fix the screen to the tube, which were listed to facilitate identification. 


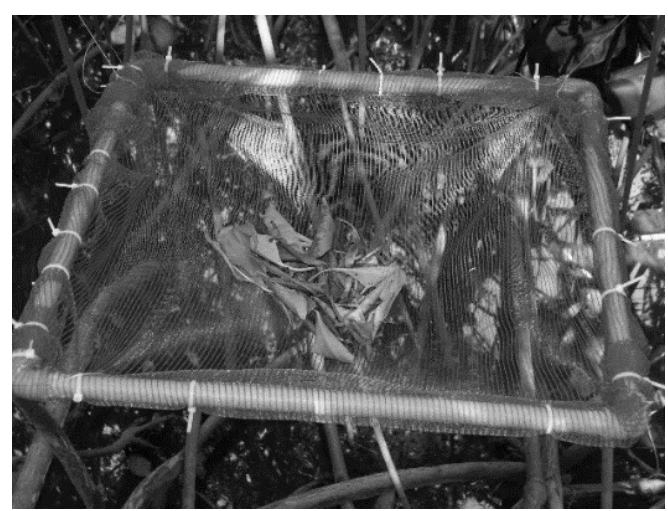

Figure 1. Litterfall collectors installed in each forest station evaluated in the Costinha mangrove forest, São Francisco River Estuary, Sergipe state, Brazil.

Figura 1. Cesta coletora confeccionada e instalada em cada floresta de mangue avaliada na Costinha, estuário do Rio São Francisco, estado de Sergipe, Brasil.

Litterfall collectors were installed in February 2009, and litter collections started one month later lasting two years (March 2009 to March 2011). According to Scheer et al. (2009), this period is considered acceptable for this type of study. The material collected in the field was packed in plastic bags, with identification of the forest station and date of collection. In the laboratory, the material of each litterbag was air-dried, ensuring the aforementioned identification for further sorting. After drying, the material was separated into fractions: leaf, flower, fruit, branch and twig, stipe and miscellaneous, and the leaves and fruits were separated by species and packed in paper bags for drying in air-circulation oven at $60^{\circ} \mathrm{C}$ until constant weight was obtained. The dry mass was taken using a precision scale (BACKES et al., 2005)

For each forest station, the annual litterfall production was calculated by adding the average monthly production values. These values were multiplied by the area of each forest station to calculate the total litterfall production of the Costinha mangrove, considering the conversion of production in ton per hectare per year (ton $\mathrm{ha}^{-1}$.year-1) (SANTOS et al., 2017).

Statistical analysis (ANOVA) was carried out using the SISVAR 5.1 software to compare the production of the fractions between the forest stations, and the Tukey's test was applied with significance level of $95 \%$ (FERREIRA, 2011).

\section{RESULTS}

The average annual litterfall production in the different Costinha mangrove forests was $13.53 \mathrm{t} \mathrm{ha}^{-1}$ year $^{-}$ ${ }^{1}$ in the first year and $13.21 \mathrm{t} \mathrm{ha}^{-1}$ year ${ }^{-1}$ in the second year, and no statistically significant differences $(p>0.05)$ between the years was observed in the period evaluated. In general, the litterfall production in fractions presented the following decreasing order (Figure 2): leaves > branches and twigs > stipules > fruits and propagules > miscellaneous $>$ flowers, with the leaf fractions accounting for $71.46 \%$ of production in every season.

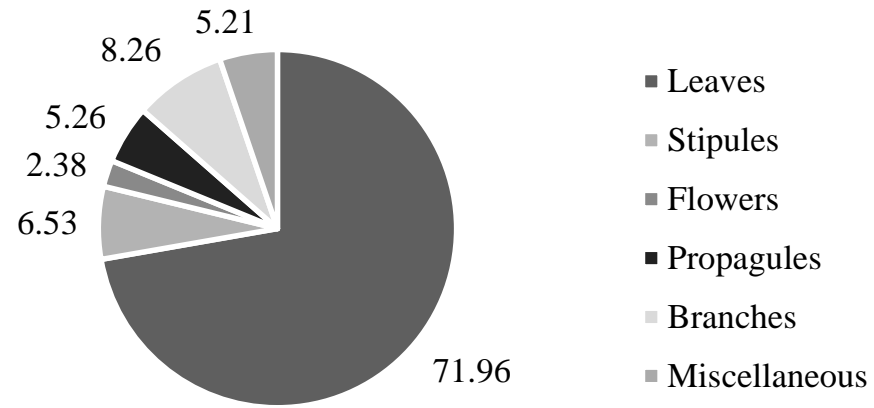

Figure 2. Percentage of litterfall production by fraction in two years of monitoring, Costinha mangrove forest, São Francisco River Estuary, Sergipe state, Brazil.

Figura 2. Percentual da produção de serapilheira por fração em dois anos de monitoramento, manguezal da Costinha, estuário do rio São Francisco, estado de Sergipe, Brasil.

FLORESTA, Curitiba, PR, v. 49, n. 4, p. 813 - 820, out/dez 2019.

Santos, T. O. et.al.

ISSN eletrônico 1982-4688

DOI: $10.5380 /$ rf.v49 i4.59458 
Litterfall production presented statistically different total values ( $p \leq 0.05)$, suggesting greater production in station B compared with those of the other stations (Table 1).

Table 1. Mean and standard deviation of total production $\left(\mathrm{g} \mathrm{m}^{-2} \mathrm{day}^{-1}\right)$ and litter fractions per forest station, Costinha mangrove forest, Sao Francisco River Estuary, Sergipe state, Brazil

Tabela 1. Média e Desvio Padrão da produção de serapilheira total e frações $\left(\mathrm{g} \mathrm{m}^{-2} \mathrm{dia}^{-1}\right)$ por estação no manguezal da Costinha, estuário do Rio São Francisco, estado de Sergipe, Brasil.

\begin{tabular}{lccccc}
\hline \multicolumn{1}{c}{ Fractions / Station } & $\mathrm{A}$ & $\mathrm{B}$ & $\mathrm{C}$ & $\mathrm{D}$ & $\mathrm{E}$ \\
\hline Leaves & $2.34 \pm 0.71^{*}$ & $2.54 \pm 0.66$ & $2.29 \pm 0.60$ & $2.05 \pm 0.04$ & $2.49 \pm 1.08$ \\
Stipules & $0.21 \pm 0.06$ & $0.32 \pm 0.07$ & $0.18 \pm 0.06$ & $0.18 \pm 0.04$ & $0.17 \pm 0.07$ \\
Flowers & $0.08 \pm 0.12$ & $0.19 \pm 0.16$ & $0.12 \pm 0.16$ & $0.07 \pm 0.08$ & $0.12 \pm 0.16$ \\
Propagules & $0.22 \pm 0.64$ & $0.24 \pm 1.08$ & $0.20 \pm 0.67$ & $0.08 \pm 0.38$ & $0.09 \pm 0.37$ \\
Branches & $0.38 \pm 0.30$ & $0.17 \pm 0.17$ & $0.35 \pm 0.41$ & $0.19 \pm 0.17$ & $0.25 \pm 0.83$ \\
Miscellaneous & $0.20 \pm 0.13$ & $0.18 \pm 0.10$ & $0.20 \pm 0.09$ & $0.13 \pm 0.06$ & $0.15 \pm 0.10$ \\
\hline Total & $3.70 \pm 1.15 \mathrm{~b}$ & $4.14 \pm 1.27 \mathrm{a}$ & $3.65 \pm 1.11 \mathrm{~b}$ & $2.76 \pm 0.54 \mathrm{~d}$ & $3.33 \pm 1.42 \mathrm{c}$ \\
\hline * Means followed by the same letters in the line do not differ significantly by the Tukey test $(\mathrm{p}<0.05)$. &
\end{tabular}

It was also verified that the fractions "flowers" and "fruits and propagules" presented high standard deviation, being in some cases higher than the mean itself. The Costinha mangrove forests presented four peaks of litterfall production: two in the first year of collection, in May and November 2009 (4.69 and $4.62 \mathrm{~g} \mathrm{~m}^{-2} \mathrm{day}^{-1}$, respectively), and two in the second year of collection, in August 2010 and January 2011 (3.66 and $4.73 \mathrm{~g} \mathrm{~m}^{-2} \mathrm{day}^{-}$ ${ }^{1}$, respectively) (Figure 3).

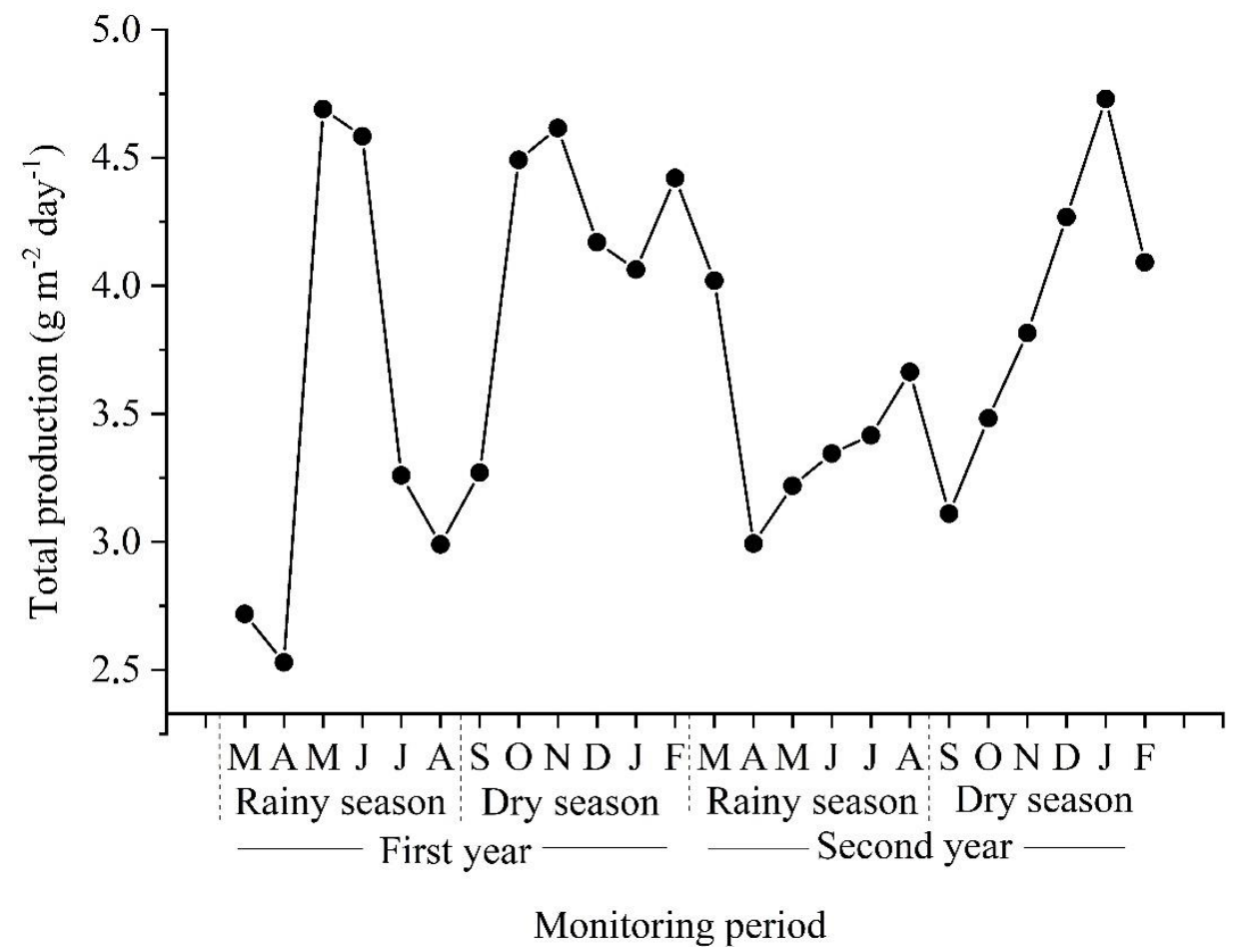

Figure 3. Changes in the mean litterfall production in the two years of monitoring, Costinha mangrove forest, São Francisco River Estuary, Sergipe state, Brazil.

Figura 3. Variação temporal da produção média de serapilheira em dois anos de monitoramento, manguezal da Costinha, estuário do rio São Francisco, estado de Sergipe, Brasil. 
The mangrove forests assessed showed variable litterfall production rates throughout the study period, but there was an increasing trend in leaf fall in warmer seasons- September 2009 to January 2010 (Figure 4).
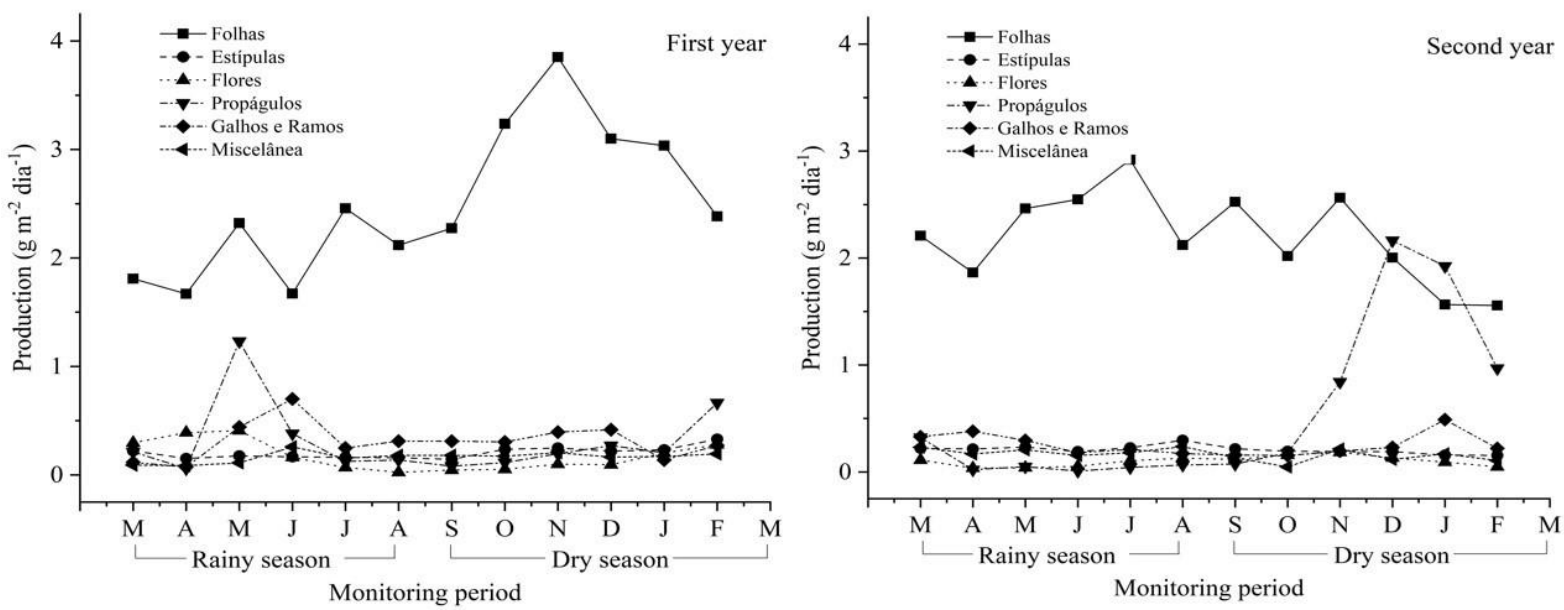

Figure 4. Average monthly production per litter fraction in the two years of monitoring, Costinha mangrove forest, São Francisco River Estuary, Sergipe state, Brazil.

Figura 4. Produção média mensal da serapilheira por frações em dois anos de monitoramento, manguezal da Costinha, estuário do rio São Francisco, estado de Sergipe, Brasil.

Regarding the reproductive parts (flowers and propagules), greater dispersion was observed in the rainy season, from March to August, with production close to zero in the rest of the year. The highest peak of litterfall production in the rainy season was verified in the first year of monitoring (November 2009). As for the litterfall production by species (Figure 5), there was greater contribution of the Rhizophora mangle species.

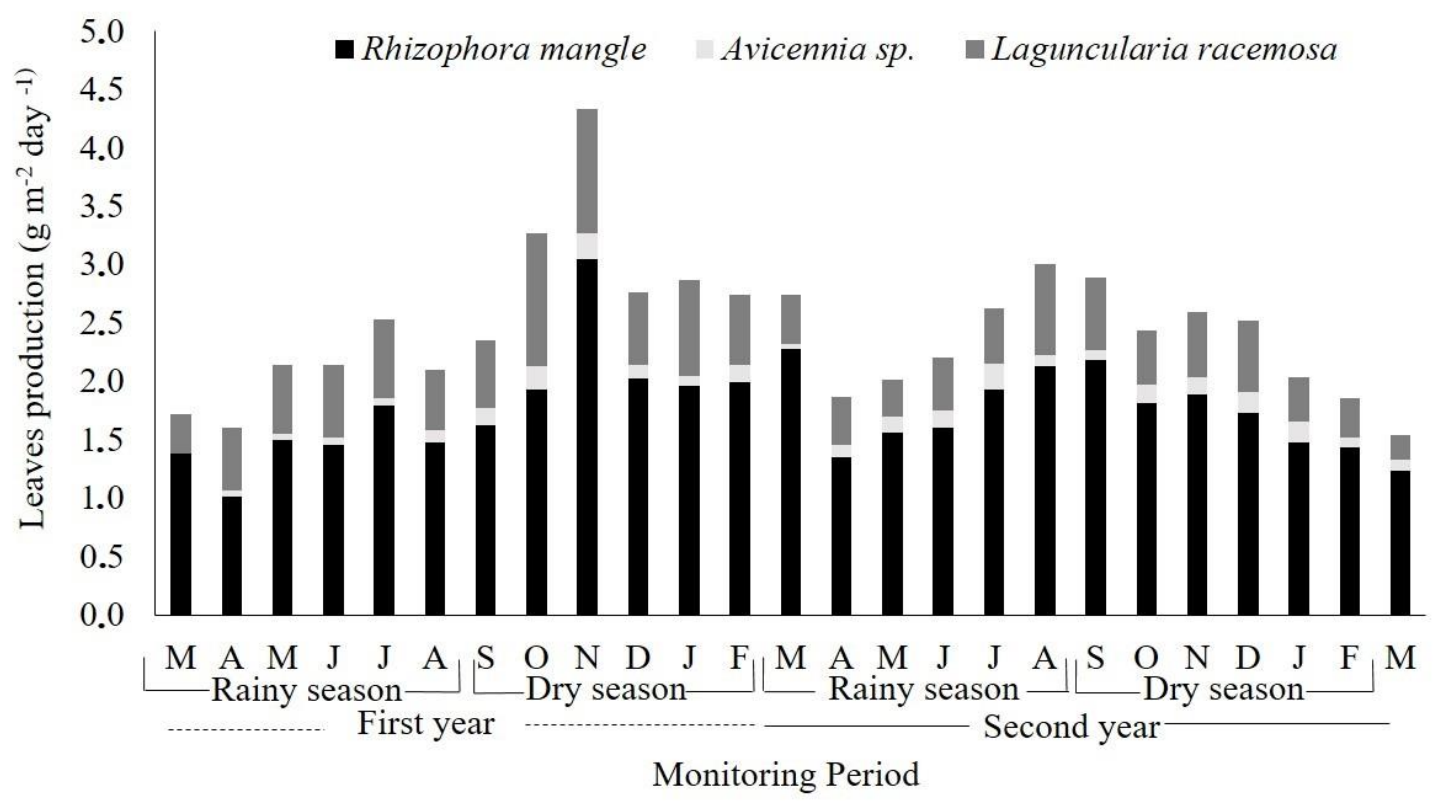

Figure 5. Monthly leaf production by species in two years of monitoring in the Costinha mangrove forest, São Francisco River Estuary, Sergipe state, Brazil.

Figura 5. Produção mensal de folhas por espécie em dois anos de monitoramento no manguezal da Costinha, no estuário do rio São Francisco, estado de Sergipe, Brasil. 


\section{DISCUSSION}

Litterfall production in the study area was within the range reported for other Brazilian mangroves, namely, Bernini and Rezende (2010) in the mangrove of the Paraíba do Sul River estuary (13.1 $\mathrm{t} \mathrm{ha}^{-1}$ year $\left.^{-1}\right)$ and Fernandes et al. (2007) in Furo Grande mangrove, Bragança peninsula, Pará state $\left(9.85\right.$ ton $^{-1}$ year $\left.^{-1}\right)$.

The greater contribution of the "leaf" fraction can be justified by its representativeness in the plant, as well as because it has been verified that its production is uninterrupted throughout the annual cycle, as ratified by Fernandes et al. (2007), and because of its adjustments in favorable periods and unfavorable vegetative and reproductive cycles of plant species (SILVA et al., 2009). Similar behaviors were reported by Sales et al. (2009) in the Furo Grande mangrove, Bragança peninsula, Pará state, as well as in other ecosystems, as by Cianciaruso et al. (2006) in the "cerradão" at the Ecological Station of Jataí, São Paulo state.

The annual litterfall production of the Costinha mangrove was superior to that found by Farias et al. (2006), who also evaluated mixed forests on the Bragança peninsula, Pará state (4.93 ton ha $^{-1}$ year $^{-1}$ ). This behavior is justified by the retreat of the coastline, which caused gradual sedimentation, slowly burying an expressive area (SANTOS et al., 2011), and thus promoted a phenological stress on the species, observed by the greater fall of leaves and reproductive parts (flowers and propagules).

The coastal mangrove forests of the Costinha present similar pattern of structural development and are composed of mixed forests of Rhizophora mangle and Laguncalaria racemosa and, in some areas, of Avicennia sp., but a difference of 8.6 ton ha $^{-1} \cdot$ year $^{-1}$ is observed in the comparison between these studies using the phytosociological data by Santos et al. (2012).

The high standard deviation, which in some cases is higher than the mean, is a characteristic commonly attributed to the great seasonality of litterfall, especially in the mangrove ecosystem (BARROSO-MATOS, 2012).

These peaks of production in May 2009 and April 2010 correspond to the period of dispersion of reproductive parts (flowers and propagules), behaving in advance if compared with the two years. The peak of November 2009 was related to an increase in leaf fall, and that of June 2010 was associated with the greater fall of "branches and twigs", the end of the propagation period, and with increased leaf abscission. Mangrove abscission usually occurs more intensely in periods when there is an increase in daytime, i.e., higher exposure to solar radiation (FERNANDO; BANDEIRA, 2009), but the branches did not follow the same behavior, registering higher values between May and August, which is the rainy season in the region.

This behavior is associated with the phenology of the species occurrence in the area, since the dispersal of propagules by hydrocoria is observed during the rainy season, as reported by Fernandes et al. (2007).

This peak of leaf production in the rainy season in the first year of the study can be assigned to the lower salinity of the soil due to greater rainfall. In these conditions, the flow velocity is also altered and salinity is reduced, which can be observed by the increase of sediments and nutrients in coastal waters (Mehlig et al., 2006).

It is worth noting that the lower litterfall production of the species Laguncularia racemosa and Avicennia sp. is due to the reduced number of individuals recorded in the Costinha mangrove, making further studies in the São Francisco River Estuary mangrove that incorporate these species necessary for possible comparisons between them.

\section{CONCLUSIONS}

- Monitoring of litterfall production in the Costinha mangrove forests allowed identification of important phenological periods, such as the propagation of leaves that occur in the months of May and June.

- The estimate obtained for the average litterfall production in the Costinha mangrove, monitored for two years, was $13.37 \pm 2.01$ ton $\mathrm{ha}^{-1}$.year-1, with the "leaf" compartment as the main contributor.

- Species of the Costinha mangroves present a trend of reproductive peaks in times of high precipitation.

\section{REFERENCES}

ADMINISTRAÇÃO ESTADUAL DO MEIO AMBIENTE (ADEMA). Seminário do Levantamento Quantitativo do Manguezal de Sergipe. Disponível em: <http://www.adema.se.gov.br/modules/news/article> Acesso em: 01 out. 2012.

ABOHASSAN, R. A. A.; OKIA, C. A.; AGEA, J. G.; KIMOND, J. M. e McDONALD, M. M. Perennial biomass production in arid mangrove system on the red sea cost of Saudi Arabia. Environmental Research, Catalonia, v. 6, n. 1, p. 22-31, 2012. 
BACKES, A., PRATES, F. L., Viola, M. G. Produção de serapilheira em floresta ombrófila mista, em São Francisco de Paula, Rio Grande do Sul, Brasil. Acta botânica brasílica, Belo Horizonte, v. 19, p. 155-160, 2005

BARROSO-MATOS, T.; BERNINI, E.; REZENDE, C.s E. Decomposition of mangrove leaves in the estuary of Paraiba do Sul River Rio de Janeiro, Brazil/Descomposición de hojas de mangle en el estuario del Rio Paraiba do Sul Rio de Janeiro, Brasil. Latin American Journal of Aquatic Research, Valparaíso, v. 40, n. 2, p. 398, 2012.

BERNINI, E.; REZENDE, C. E. Litterfall in a mangrove in Southeast Brazil. Pan-American Journal of Aquatic Sciences, Rio Grande do Sul, v. 5, n. 4, p. 508-519, 2010.

BROWN, S. GILLESPIE, A. J. R.; LUGO, A. E. Biomassestimetion methods for tropical forests with applications to forest inventory data. Forest Science, Bethesda, v. 35, n. 4, p. 881-902, 1989.

CIANCIARUSO, M. V.; PIRES, J. S. R.; DELITTI, W. B. C.; SILVA, E. F. L. P. da. Produção de serapilheira e decomposição do material foliar em um cerradão na Estação Ecológica de Jataí, município de Luiz Antônio, SP, Brasil. Acta botânica brasílica, Belo Horizonte, v. 20, n. 1, p. 49-59, 2006

FARIAS, A. do S. C.; FERNANDES, M. E. B.; REISE, A. Comparação da produção de serapilheira de dois bosques de mangue com diferentes padrões estruturais na península Bragantina, Bragança, Pará. Boletim do Museu Paraense Emílio Goeldi Ciências Naturais, Belém, v. 1, n. 3, p. 53-60, 2006.

FERNANDES, M. E. B.; NASCIMENTO, A. A. M. do; CARVALHO, M. L., Estimativa da produção anual de serapilheira dos bosques de mangue no Furo Grande, Bragança, Pará. Revista Árvore, Viçosa, v. 31, n. 5, p. 949-958, 2007.

FERNANDO, S. M. C.; BANDEIRA, S. O. Litter fall and decomposition of mangrove species Avicennia marina and Rhizophora mucronata in Maputo Bay, Mozambique. Western Indian Ocean Journal of Marine Science, Zanzibar, v. 8, n. 2, p. 173-182, 2009.

FERREIRA, D. F. Sisvar: a computer statistical analysis system. Ciência e Agrotecnologia, Lavras, v.35, n.6, p.1039-1042, 2011.

GAO, C., HE, J., CONG, J., ZHANG, S., WANG, G. Impact of forest fires generated black carbon deposition fluxes in Great Hinggan Mountains (China). Land degradation \& development, v. 29, n. 7, p. 2073-2081, 2018.

GIBBS, H. K.; BROWN, S.; NILES, J. O.; FOLEY, J. A. Monitoring and estimating tropical forest carbon stocks: making REDD a reality. Environmental Research Letters, Bristol, v. 2, n. 4, p. 1-13, 2007.

LARCHER, L.; BOEGER, M. R. T.; NOGUEIRA, G.; REISSMANN, C. B. Produção de serapilheira em dois manguezais do estado do Paraná, Brasil. Acta Biológica Catarinense, Joinvile, v. 1, n. 1, p. 53- 64, 2014.

MEHLIG, U. Phenology of the red mangrove, Rhizophora mangle L., in the Caeté estuary, Pará, Equatorial Brazil. Aquatic Botany, Madri, v. 84, n. 2, p. 158-164, 2006.

NASCIMENTO, R. E. S. A.; MEHLIG, U.; ABREU, M. M. O.; MENEZES, M. P. M. de. Produção de serapilheira em um fragmento de bosque de terra firme e um manguezal vizinhos na península de Ajuruteua, Braganca, Pará. Ciências naturais, Belém, v. 1, n. 3, p. 71-76, 2006.

SALES, J. B. de L.; MEHLIG, U.; NASCIMENTO, J. R.; RODRIGUES FILHO, L. F.; MENEZES, M. P. M. de Análise estrutural de dois bosques de mangue do rio Cajutuba, município de Marapanim, Pará, Brasil. Boletim do Museu Paraense Emílio Goeldi, Ciências Naturais, Belém, v. 4, n. 1, p. 27-35, 2009.

SANTOS, H. V. S.; SANTOS, T. O.; HOLANDA, F. S. R. Indicadores para diagnóstico das alterações antrópicas no manguezal do estuário do rio São Francisco. Tropical Oceanography, Recife, v. 39, n. 2 , p. 166-178, 2011.

SANTOS, H. V. S., HOLlANDA, F. S. R., SANTOS, T. D. O., ANDRADE, K. V. S. D., SANTANA, M. B. S., ESTRADA, G. C. D., SOARES, M. L. G. Allometric models for estimating the aboveground biomass of the mangrove Rhizophora mangle. Brazilian Journal of Oceanography, São Paulo, v. 65, n. 1, p. 44-53, 2017. 
SANTOS, T. O.; ANDRADE, K. V. S.; SANTOS, H. V. S.; CASTANEDA, D. A. F. G.; SANTANA, M. B. S.; HOLANDA, F. S. R.; SANTOS, M. J. C. Caracterização estrutural de bosques de mangue: Estuário do São Francisco. Scientia Plena, São Cristóvão, v. 8, n. 4, p.3-15, 2012.

SCHAEFFER-NOVELLI, Y.; CINTRÓN-MOLERO, G.; REIS-NETO, A. S.; ABUCHAHLA, G. M.; NETA, L. C.; LIRA-MEDEIROS, C. F. The mangroves of Araçá Bay through time: An interdisciplinary approach for conservation of spatial diversity at large scale. Ocean \& coastal management, Netherlands, v. 164, p. 6067, 2018.

SCHEER, M. B.; GATTI, G.; WISNIEWSKI, C.; MOCOCHINSKI, A. Y.; CAVASSANI, A. T.; LORENZETTO, A.; PUTINI, F. Patterns of litter production in a secondary alluvial Atlantic Rain Forest in southern Brazil. Revista Brasileira de Botânica, São Paulo, v.32, n.4, p.805-817, 2009.

SILVA, C. J. da, LOBO, F. de A., BLEICH, M. E., SANCHES, L. Contribuição de folhas na formação da serrapilheira e no retorno de nutrientes em floresta de transição no norte de Mato Grosso. Acta Amazônica, Manaus, v. 39, n. 3, p. 591-600, 2009.

SOUZA, M. M. A.; SAMPAIO, E. V. S. B. Predation on propagules and seedlings in mature and regenerating mangroves in the coast of Ceará, Brazil. Hydrobiologia, Heidelberg, v. 661, n. 1, p. 179-186, 2011.

VENDRAMI, J. L.; JURINITZ, C. F.; CASTANHO, C. de T.; L. LORENZO, L.; OLIVEIRA, A. A. de. Litterfall and leaf decomposition in forest fragments under different successional phases on the Atlantic Plateau of the state of Sao Paulo, Brazil. Biota Neotropica, Campinas, v. 12, n. 3, p. 136-143, 2012. 